\title{
Management tools for Castanea sativa coppice stands in northwestern Spain
}

\author{
Herramientas de gestión para masas de monte bajo de Castanea sativa en el noroeste de España
}

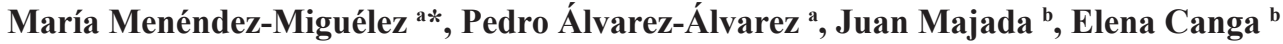 \\ *Corresponding author: ${ }^{a}$ University of Oviedo, Department of Organisms and Systems Biology, GIS-Forest Group, \\ Polytechnic School of Mieres, Mieres, Spain, tel.: 0034985458000 ext.5857, maria.mndz.m@gmail.com \\ ${ }^{\mathrm{b}}$ Forest and Wood Technology Research Centre (CETEMAS), Grado, Asturias, Spain.
}

\begin{abstract}
SUMMARY
The importance of chestnut coppice stands in northwestern Spain, together with the almost total lack of growth and yield studies, makes the development of applicable tools to facilitate forest management necessary. In the present study two management tools were developed: variable-density yield tables and stand density management diagrams (SDMDs). For constructing the yield tables, a dominant height growth model and a stand density model were fitted. The dominant height growth model was necessary for estimating site index, i.e., for indirectly assessment of site quality. A stand density model was necessary because the silvicultural stages of the stands were very heterogeneous. Both yield tables and SDMDs require fitting models for predicting quadratic mean diameter and growing stock (total or merchantable stand volume and/or total or component stand biomass). Eight yield tables were constructed considering two stand density levels (high and low) and four site indices $(8,12,16$ and $20 \mathrm{~m}$ ). Rotation lengths producing maximum sustainable yield ranged between 25 and 45 years depending on stand density class and site index. Average growth at these rotation lengths varied from $38.1 \mathrm{~m}^{3} \mathrm{ha}^{-1}$ year ${ }^{-1}$ for the highest density and best quality, to $5.2 \mathrm{~m}^{3} \mathrm{ha}^{-1}$ year ${ }^{-1}$ for the lowest density and poorest quality. Both the yield tables and the SDMDs developed allow estimation of total and merchantable stand volume, total and component stand biomass and also facilitate the design of silvicultural schedules.
\end{abstract}

Key words: chestnut coppice, yield tables, stand density management diagrams, site index, thinning schedules.

\section{RESUMEN}

La importancia del monte bajo de castaño en el noroeste de España, junto con la falta de estudios de crecimiento y producción, hacen necesario el desarrollo de herramientas que faciliten su gestión. En este estudio se han desarrollado dos herramientas de gestión: tablas de producción de densidad variable y diagramas de manejo de densidad (DMDs). Para la construcción de las tablas de producción se ajustaron un modelo de altura dominante y uno de densidad de masa. El modelo de altura dominante proporciona el índice de sitio, es decir, estimar indirectamente la calidad de estación. Se necesitó un modelo de densidad porque los escenarios selvícolas eran muy heterogéneos. Tanto las tablas de producción como los DMDs requieren el ajuste de modelos de predicción de diámetro medio cuadrático y stock de crecimiento (volumen total y comercial de masa y/o biomasa total o por componentes). Se construyeron ocho tablas de producción considerando dos niveles de densidad de masa (alta y baja) y cuatro índices de sitio (8, 12, 16 y $20 \mathrm{~m}$ ). El turno de máxima renta en especie varió entre 25 y 45 años según la clase de densidad y el índice de sitio. El crecimiento medio osciló desde $38,1 \mathrm{~m}^{3}$ ha $^{-1}$ año ${ }^{-1}$ para las densidades más elevadas y mejores calidades, hasta $5,2 \mathrm{~m}^{3}$ ha $^{-1}$ año-1 en las densidades más bajas y peores calidades. Las herramientas de gestión desarrolladas permiten la estimación del volumen total y comercial de masa, biomasa total y por componentes y también facilitan el diseño de esquemas selvícolas.

Palabras clave: monte bajo de castaño, tablas de producción, diagramas de manejo de densidad, índice de sitio, esquemas selvícolas.

\section{INTRODUCTION}

The European Natura 2000 network recognized chestnut (Castanea sativa Mill.) forests as habitats of interest and considered them as characteristic cultural landscapes of the Mediterranean and Atlantic regions (Díaz Varela et al. 2009). More than $90 \%$ of all chestnut stands in Spain are located in the northwest of the country (DGCONA 2013). The chestnut coppice stands currently existing in north-western Spain were established after the $18^{\text {th }}$ cen- tury. However, during the last 30-60 years, many traditional coppice stands have been abandoned or the rotation length has been significantly increased, resulting in degraded and unstable stands. Due to the ethnographic, economic and productive importance of the species, public administrations and stakeholders are now demanding active management to yield the best performance, in terms of both profitability and long-term sustainability.

Accurate estimation of forest site quality and growing stock, in terms of volume and biomass is essential for forest 
management. Management tools such as dominant height growth models, stand biomass or volume equations, yield tables or stand density management diagrams (SDMDs) are therefore necessary to establish the current and future situation of the stands, as well as to optimize stand management.

The first step in any study related to growth and yield modeling for any species is the classification of sites according to their quality. Methods based on the height development of the upper canopy are the most accurate and commonly used for productivity assessment in even-aged stands (Burkhart and Tomé 2012). Typically, the site quality for a certain species is described by a site index.

The second step involves acquiring information about the growing stock in relation to the initial spacing and/or subsequent thinning. When only one initial plot inventory covering a wide range of ages, densities and sites is available for a certain species, only static models may be developed. Yield tables and SDMDs are currently the most used types of static models (e.g., Diéguez-Aranda et al. 2009).

Yield tables are defined by Madrigal (1991) as numerical tables that project the development of stand variables over time in an even-aged stand of a certain species. If different density schedules are carried out in the sample plots, density should be included as an independent variable in the stand projection system. Yield tables are commonly termed variable-density yield tables (Burkhart and Tomé 2012).
Stand density management diagrams are graphical models that integrate relationships between yield and density throughout all stages of stand development (Newton et al. 2005). The use of these diagrams is one of the most effective methods of designing and evaluating alternative density management regimes in even-aged stands.

Despite the economic importance of Castanea sativa in northwestern Spain or elsewhere, there are no many studies of its growth and yield. This aspect strengthens the importance of the development of these equations and tools that are not currently available for chestnut coppice stands. Therefore, the aim of the present study is to develop height growth models, stand volume and biomass equations, yield tables and SDMDs to facilitate the management of the species in the area of study.

\section{METHODS}

Data. A network of 70 permanent plots was established in chestnut coppice stands to cover the existing range of sites, ages and stand densities in the area of distribution of the species in northwestern Spain (figure 1). The observed range of values in the established plots (table 1) presented consolidated stands, with high densities; some of them presenting ages higher than the traditional rotation length for chestnut coppice stands.

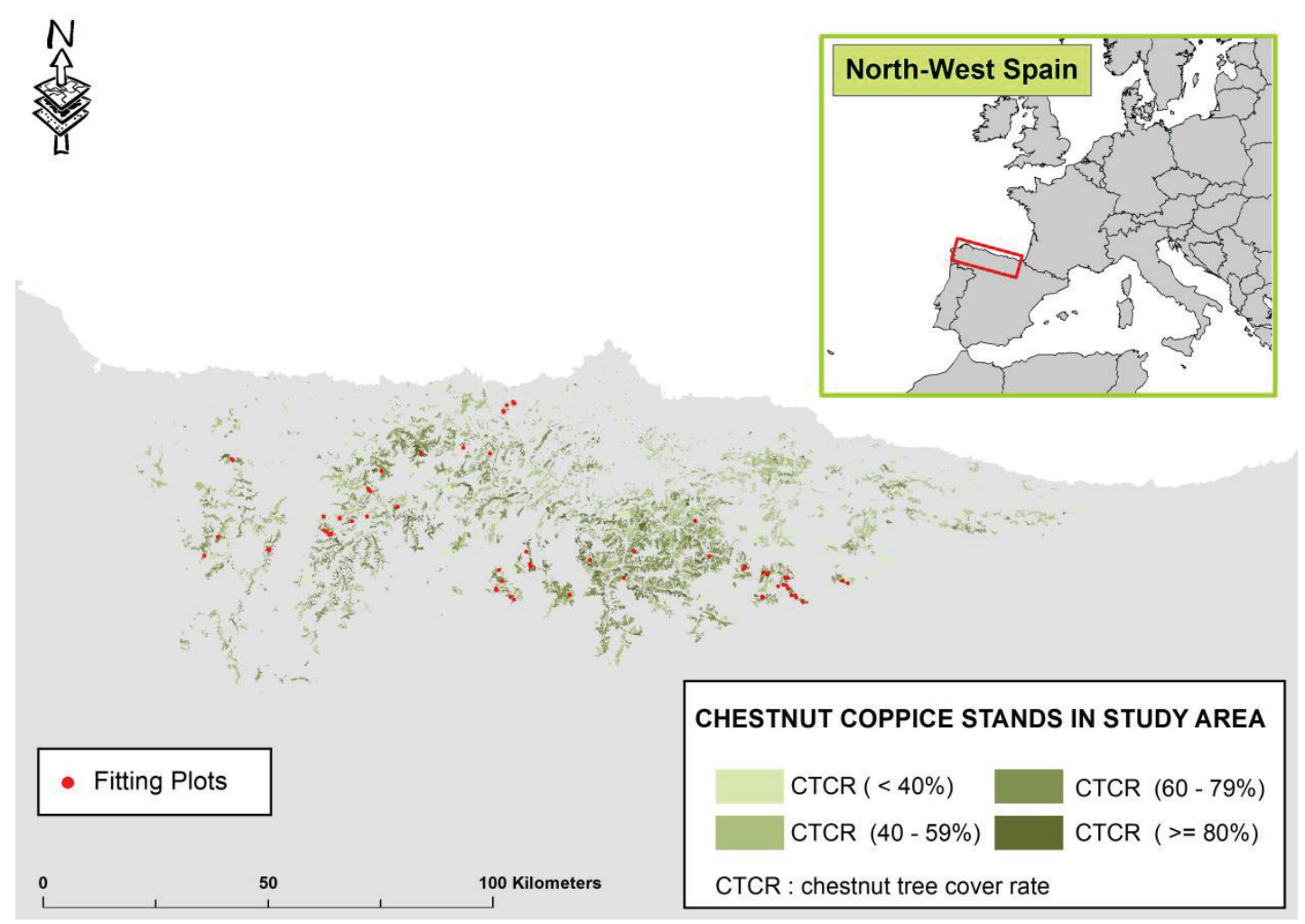

Figure 1. Map showing cover rates for chestnut coppice stands in the study area. Fitting plots are indicated by red dots.

Mapa que muestra las tasas de cobertura de masas de monte bajo de castaño en el área de estudio. Las parcelas de muestreo están indicadas con puntos rojos. 
Table 1. Descriptive statistics of main stand variables.

Estadísticos descriptivos de las principales variables de masa.

\begin{tabular}{cccccc}
\hline Parameter & $\mathrm{n}$ & \multicolumn{1}{c}{ Mean } & Minimum & Maximum & Standard deviation \\
\hline $\mathrm{t}$ & 53 & 39.57 & 15 & 55 & 9.758 \\
$\mathrm{~N}$ & 55 & 1230.80 & 396.12 & 3154.80 & 541.70 \\
$\mathrm{~d}_{\mathrm{g}}$ & 55 & 21.21 & 9.56 & 30.98 & 4.41 \\
$\mathrm{G}$ & 55 & 39.53 & 16.33 & 58.76 & 9.81 \\
$\mathrm{H}_{0}$ & 55 & 20.36 & 12.37 & 28.17 & 3.15 \\
$\mathrm{RS}$ & 55 & 16.11 & 11.70 & 24.51 & 2.79 \\
$\mathrm{SI}$ & 53 & 14.13 & 9.88 & 23.53 & 2.64 \\
$\mathrm{~V}$ & 55 & 334.41 & 97.82 & 543.17 & 104.74 \\
\hline
\end{tabular}

$\mathrm{n}$ : number of plots available for each stand variable, t: age (years), N: stand density (stems ha $\left.{ }^{-1}\right), \mathrm{d}_{\mathrm{s}}$ : quadratic mean diameter $(\mathrm{cm}), \mathrm{G}$ : stand basal area $\left(\mathrm{m}^{2} \mathrm{ha}^{-1}\right), \mathrm{H}_{0}$ : average height of the 100 thickest stems per hectare $(\mathrm{m})$, RS: relative spacing index $(\%)$ (staggered distribution), SI: site index (m, defined as the stand dominant height at a reference age of 20 years), $\mathrm{V}$ : stand volume $\left(\mathrm{m}^{3} \mathrm{ha}^{-1}\right)$.

$\mathrm{n}=$ número de parcelas disponible para cada variable de rodal, $\mathrm{t}=$ edad $($ años $), \mathrm{N}=$ densidad (pies ha $\left.{ }^{-1}\right), \mathrm{d}_{\mathrm{g}}=$ diámetro medio cuadrático $(\mathrm{cm}), \mathrm{G}=$ área basal $\left(\mathrm{m}^{2} \mathrm{ha}^{-1}\right), \mathrm{H}_{0}=$ altura media de los 100 pies más gruesos por hectárea $(\mathrm{m}), \mathrm{RS}=$ índice de espaciamiento relativo (\%) (distribución a tresbolillo), $\mathrm{SI}=$ índice de sitio $\left(\mathrm{m}\right.$, a la edad de referencia de 20 años), $\mathrm{V}=$ volumen por hectárea $\left(\mathrm{m}^{3} \mathrm{ha}^{-1}\right)$.

For all trees within the plots, diameter at breast height and total height was measured. Additionally, variables such as stand health and stand age were also recorded (see Menéndez-Miguélez et al. (2013) for more details).

Stem analysis data were obtained by felling dominant trees in areas adjoining 58 of these plots. The trees were selected according to the methodology proposed by Madrigal et al. (1992), based on that previously established by the British Forestry Commission (Hummel et al. 1959). All selected trees were healthy, well-shaped and belonged to the upper canopy of the stand.

The cross-sectional disks were obtained at the stem base just above the stool and at $1 \mathrm{~m}$ intervals thereafter until a top diameter of $7 \mathrm{~cm}$. The exact height above ground and the diameters (with and without bark) at the points where the disks were removed were measured. Growth ring counts and heights for the cross section disks were used to estimate height-age pairs.

To develop the static models only plots belonging to pure stands (less than $10 \%$ of other species, in this study) are recommended. As a consequence, 15 of the plots installed in mixed stands were not considered for analyses. Additionally, two plots were cut before the end of this study, hampering to know their stand ages. Therefore, 55 plots were used for the development of SDMDs and 53 for the yield tables (which required knowing the stand age).

Construction of the management tools. For constructing the variable-density yield tables, a dominant height growth model and a stand density model must be firstly developed. The dominant height growth model is necessary for estimating site index, i.e., for indirect assessment of the site quality. A stand density model is necessary in the pre- sent study because the silvicultural stages of the stands are very heterogeneous, as reflected by the high variation in stand density existing for a given age or dominant height. Therefore, grouping the sample plots according to their evolution of stand density over age is required; otherwise it is difficult to develop an accurate yield table, and their results may lack practical value (Sánchez et al. 2003).

Stand density management diagrams, SDMDs. Both yield tables and SDMDs require models for predicting quadratic mean diameter and growing stock (total or merchantable stand volume and/or total or component stand biomass). Diagrams characterize the growing stock with indices that relate average tree size to density. Several density indices have been used: the stand density index (Reineke 1933), the self-thinning rule (Yoda et al. 1963), the relative density index (Drew and Flewelling 1979) and the relative spacing index (RS) (Wilson 1946). All of these indices present the enormous advantage of being independent of site quality and stand age (McCarter and Long 1986). For constructing SDMDs, it is preferable that dependent variables only depend on dominant height and stand density, and therefore only these variables were used. For yield tables, this constrain does not apply and therefore the selection of the stand variables for each submodel can be optimized. In the system proposed in this study, dominant height was represented on the $\mathrm{x}$-axis and the number of stems per hectare in logarithmic scale on the $\mathrm{y}$-axis. The RS was used to characterize the growing stock level.

Dominant height growth model. The stem analysis carried out on field underestimated the heights for a given age. This bias was corrected by using the algorithm proposed 
by Carmean (1972), with the modification proposed by Newberry (1991) for the topmost section of the tree. After a further analysis to detect abnormalities, 111 trees $(1,663$ height-age pairs of observations) were finally selected to model the variation in dominant height with age. Site curves were developed using the simplified approach of mixed-effects modeling proposed by Cieszewski (2003) by applying the GADA (generalized algebraic difference approach) to develop the equation and the dummy variables method, as described by Cieszewski and Bailey (2000), to estimate the parameters.

Three-parameter models were evaluated, and several variants of each were tested. The evaluated models were the differential function proposed by von Bertalanffy $(1949,1957)$ and studied by Richards (1959), the McDill and Amateis (1992) model and that proposed by Cieszewski (2002).

The evaluation of the growth of an individual tree over time with single time series equations often generates autocorrelation errors. For achieving this, a continuous autoregressive error structure CAR $(x)$ was used to model the error terms (Diéguez-Aranda et al. 2009). The structure was implemented using the MODEL procedure of SAS/ ETS $^{\circledR}$ (SAS Institute Inc. 2004b).

The base age for site index equations was selected according to the considerations of Goelz and Burk (1992). The results were compared with the values obtained from stem analyses and the relative error in predictions (RE\%) was calculated as follows:

$$
\mathrm{RE} \%=\frac{\sqrt{\sum_{\mathrm{i}=0}^{\mathrm{i}=\mathrm{n}}\left(Y_{\mathrm{i}}-\widehat{Y}_{\mathrm{i}}\right)^{2} /(n-p)}}{\bar{Y}} \cdot 100
$$

Where,

$Y_{\mathrm{i}}, \hat{Y}_{\mathrm{i}}$ and $\bar{Y}_{\mathrm{i}}=$ Observed, estimated and average values of tree height, respectively.

$n=$ Number of observations.

$p=$ Number of model parameters.

Stand density model. The stand density model was developed based on the methodology reported by Sánchez et al. (2003), which considers the density and its most probable development as the basis of classification. Principal components analysis was applied, using the PRINCOMP procedure of SAS/ETS ${ }^{\circledR}$ (SAS Institute Inc. 2004b), with the aim of obtaining the rotation of axes that yield the first component with maximum variance.

Quadratic mean diameter model. This model is used to predict the quadratic mean diameter $\left(\mathrm{d}_{\mathrm{g}}\right)$ of a stand on the basis of different stand variables. The power models are the most commonly used to explain the behavior of this variable. Nevertheless, in this study, different linear mo- dels were tested because the convergence was not achieved with power models.

Total and merchantable stand volume equations. The first step for constructing this model was the estimation of the total and merchantable tree volume. For this purpose, the compatible total volume and the merchantable volume equations of the compatible system of Fang et al. (2000) as reported by Menéndez-Miguélez et al. (2014), were used. Top diameters from 0.5 to $40 \mathrm{~cm}$ (with intervals of $0.5 \mathrm{~cm}$ ) were used for estimating merchantable tree volumes and creating the database of model fitting. The following volume-ratio equations were analyzed when fitting the merchantable stand volume, using quadratic mean diameter and/or dominant height as independent variables: Burkhart (1977), Clark and Thomas (1984), Reed and Green (1984) modified.

Stand biomass equations. Equations for estimating components (wood, bark and crown) and total aboveground biomass at stand level were considered. Equations to be included in the yield tables were fitted ensuring additivity of the different components in a previous study (Menéndez-Miguélez et al. 2013). Nevertheless, new models with stand density and dominant height as independent variables were fitted to be included in the SDMDs.

Model fitting and comparison. Linear and nonlinear models were fitted by the ordinary least squares method using the REG and NLIN procedure of SAS/STAT ${ }^{\circledR}$ (SAS Institute Inc. 2004a), respectively. The model performance was compared on the basis of numerical and graphical analyses of the residuals. The adjusted coefficient of determination $\left(\mathrm{R}_{\text {adj }}^{2}\right)$ and root mean square error (RMSE) were used to select the best candidate models.

\section{RESULTS}

Convergence was possible for all models analyzed, and all parameters were significant at $5 \%$ level.

Dominant height growth model. A trend in the residuals was detected in all the three dynamic models analyzed, as expected due to the longitudinal nature of the data. This trend disappeared after correction of autocorrelation (second-order continuous autoregressive error structure CAR(2)). The dynamic equation derived from the Cieszewski (2002) model was finally selected after the comparison of goodness-of-fit statistics and a graphical analysis of the four models evaluated.

The parameterized equation for the selected model (equation [2]), expressed in terms of site index estimation explained over $99 \%$ of total variability and the SI curves developed showed the individual growth trend of chestnut coppice stands in northwestern Spain. 


$$
\mathrm{SI}=\frac{\left(17.34+X_{0}\right) \cdot x_{0} \cdot t_{\text {ref }}-1.077}{1+802.6}, \text { where } X_{0}=0.5 \cdot\left[H_{0}-17.34+\sqrt{\left(H_{0}-17.34\right)^{2}+4 H_{0} \cdot 802.6 \cdot t^{-1.077}}\right], \mathrm{R}^{2}{ }_{\mathrm{adj}}=0.9891 ; \mathrm{RMSE}=0.5799(\mathrm{~m})
$$

Where, $H_{0}$ : dominant height $(\mathrm{m})$ at age $t$ (years), SI: estimated dominant height $(\mathrm{m})$ at reference age $t_{\text {ref }}$ (years), $\mathrm{R}_{\text {adj: }}^{2}$ adjusted coefficient of determination, RMSE: root mean square error.

Regarding the selection of the base age for site quality classification, ages between 20 and 30 years were superior for predicting height at other ages (figure 2). As selection of the youngest base age possible is valuable for early decision making in stand management, a base age of 20 years was selected as the best option (figure 3 ).

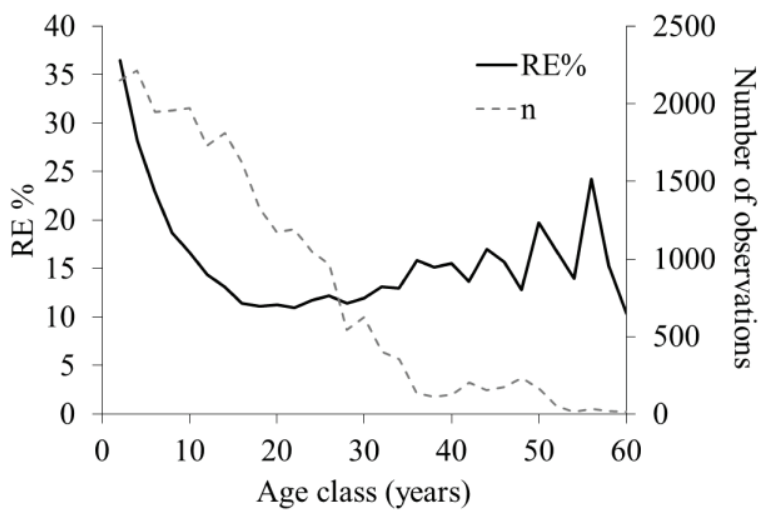

Figure 2. Relative error in height predictions for the different age classes related to choice of reference age.

Error relativo en la predicción de alturas para las diferentes clases de edad en relación con la elección de la edad de referencia.

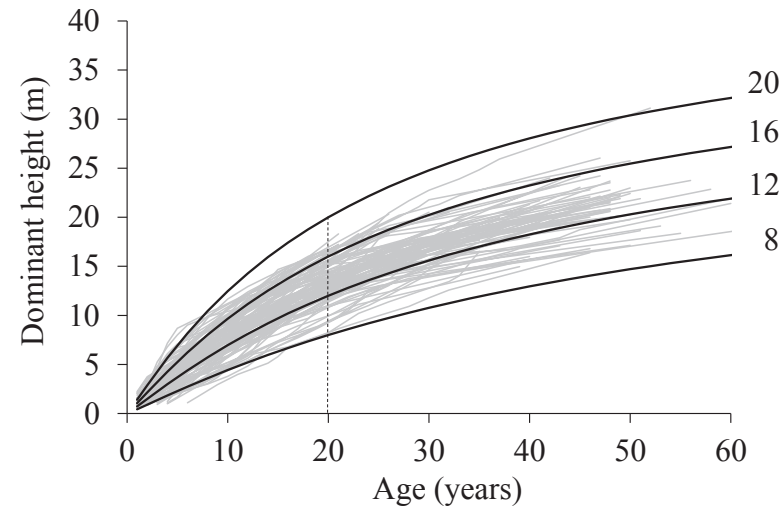

Figure 3. Dominant height growth curves for SI values of 8,12 , 16 and $20 \mathrm{~m}$ at a reference age of 20 years, overlaid on the trajectories of the observed heights over time for dynamic equation selected.

Curvas de crecimiento en altura dominante para valores del IS de $8,12,16$ y $20 \mathrm{~m}$ a la edad de referencia de 20 años, superpuestas sobre las trayectorias de las alturas observadas a lo largo del tiempo para la ecuación dinámica seleccionada.
Stand density model. Stand age was the best explanatory variable for the explaining variation in stand density, according to the results obtained in the principal component analysis ( $80.6 \%$ of the total variance). Adequate delimitation of the second principal component value enabled classification of the plots into two density classes: (i) "low density plots" and (ii) "high density plots", in order to obtain groups with a homogeneous stand density evolution in relation to stand age (figure 4). The parameterized equations [3] and [4] presented the selected density equations in the low and high density plots, respectively.

$$
\begin{gathered}
\operatorname{Ln} N=10.61-1.0825 \cdot t, \mathrm{R}^{2}{ }_{\text {adj }}=0.7363 ; \\
\operatorname{RMSE}=271.42\left(\mathrm{stems} \mathrm{ha}^{-1}\right), \\
\operatorname{Ln} N=11.58-1.172 \cdot t, \mathrm{R}^{2} \text { adj }=0.6438 ; \\
\operatorname{RMSE}=337.36\left(\mathrm{stems} \mathrm{ha}^{-1}\right),
\end{gathered}
$$

Where, $N$ : stand density (stems ha' ${ }^{-1}$ ), $t$ : stand age (years), $\mathrm{R}_{\text {adj }}^{2}$ : adjusted coefficient of determination, RMSE: root mean square error.

Quadratic mean diameter model. Selected equations, for both yield tables and SDMDs, explained more than $77 \%$ of the total variance (equations [5] and [6], respectively). Dominant height, age and stand density proved to be the best explanatory variables for the equation to be included in the yield tables. This equation was not separately fitted for plots belonging to each density classes since stand density was included as one of the independent variables. For SDMDs, the selected equation [6] explained $4 \%$ less of

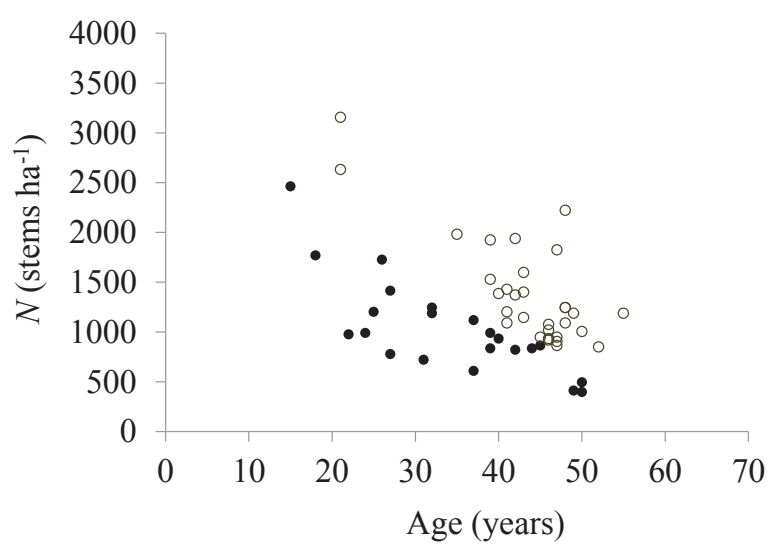

Figure 4. Classification of the sampled plots considering two density classes: high $\left({ }^{\circ}\right)$ and low $\left(\bullet^{\circ}\right.$.

Clasificación de las parcelas de muestreo considerando las dos clases de densidad: alta $\left(^{\circ}\right)$ y baja $(\bullet)$. 
the total variance than that variable used for later inclusion in the yield tables.

$$
\begin{gathered}
d_{\mathrm{g}}=5.0785 \cdot N^{-0.1775} \cdot H_{0}{ }^{0.6622} \cdot t^{0.1839}, \\
\mathrm{R}^{2}{ }_{\text {adj }}=0.8205 ; \operatorname{RMSE}=1.867(\mathrm{~cm}), \\
\operatorname{Ln} d_{\mathrm{g}}=2.143-0.2291 \cdot \operatorname{Ln} N+0.8327 \cdot \operatorname{Ln} H_{0}, \\
\mathrm{R}_{\text {adj }}^{2}=0.7688 ; \operatorname{RMSE}=2.118(\mathrm{~cm}),
\end{gathered}
$$

Where, $d_{\mathrm{g}}$ : quadratic mean diameter $(\mathrm{cm}), N$ : stand density (stems ha ${ }^{-1}$ ), $H_{0}$ : dominant height (m), $t$ : stand age (years), $\mathrm{R}_{\text {adj: }}^{2}$ : adjusted coefficient of determination, RMSE: root mean square error.

Total and merchantable volume equations. Stand basal area, stand density and dominant height were the best explanatory variables for estimating both total and merchantable volume equations, and therefore a model with these variables was selected for inclusion in the yield tables. In the first case, a merchantable volume equation was developed which explained more than $99 \%$ of total variance (equation [7]). The model to be included in the SDMDs that only depended on $\mathrm{H}_{0}$ and $\mathrm{N}$ explained about $61 \%$ of the observed variability (equation [8]). For simplicity, the SDMD represents total stand volume instead of merchantable stand volume. However, merchantable volume can be obtained at any point on the SDMD to any specific top diameter by simply multiplying the total stand volume (obtained from the diagram) by the exponential term in equation [9] ( $\mathrm{d}_{\mathrm{g}}$ is read directly from the diagram).

$$
\begin{gathered}
V_{\mathrm{i}}=0.7901 \cdot G^{1.0106} \cdot H_{0}^{0.7729} \cdot \mathrm{e}^{-0.9259 \cdot\left(\frac{d_{\mathrm{i}}}{d_{\mathrm{g}}}\right)^{3.360}} \\
\mathrm{R}_{\text {adj }}^{2}=0.9916 ; \operatorname{RMSE}=13.94\left(\mathrm{~m}^{3} \mathrm{ha}^{-1}\right), \\
\operatorname{Ln} V=-5.285+0.5220 \cdot \operatorname{Ln} N+2.455 \cdot \mathrm{LnH}_{0}, \\
\mathrm{R}_{\text {adj }}^{2}=0.6122 ; \mathrm{RMSE}=65.22\left(\mathrm{~m}^{3} \mathrm{ha}^{-1}\right), \\
R_{\mathrm{i}}=\mathrm{e}^{-0.9112 \cdot\left(\frac{d_{\mathrm{i}}}{d_{\mathrm{g}}}\right)^{3.4115}} \\
\mathrm{R}_{\text {adj }}^{2}=0.9893 ; \operatorname{RMSE}=0.04054
\end{gathered}
$$

Where, $V_{\mathrm{i}}$ : merchantable stand volume $\left(\mathrm{m}^{3} \mathrm{ha}^{-1}\right), V$ : total stand volume $\left(\mathrm{m}^{3} \mathrm{ha}^{-1}\right), R_{\mathrm{i}}$ : volume ratio equation for this diameter, $G$ : basal area $\left(\mathrm{m}^{2} \mathrm{ha}^{-1}\right), H_{0}$ : dominant height $(\mathrm{m})$, $d_{\mathrm{i}}$ : stem top diameter $(\mathrm{cm}), d_{\mathrm{g}}$ : quadratic mean diameter $(\mathrm{cm}), N$ : stand density (stems ha-1), $\mathrm{R}_{\text {adj }}^{2}$ : adjusted coefficient of determination, RMSE: root mean square error.

Stand biomass. Equations [10] - [13] show the models for estimating wood, bark, crown and total biomass by Menéndez-Miguélez et al. (2013), which were directly used in the yield tables construction. These equations were fitted simultaneously to ensure additivity of the different components. When fitting biomass equations to be included in the SDMDs (which only can depend on stand density and dominant height) convergence was only possible for a stem biomass equation (combining wood and bark components) and a total biomass equation. The fitted equations [14] - [15] explained more than $67 \%$ and $57 \%$ of the variance in stem and total biomass, respectively.

$$
\begin{aligned}
& W_{\text {wood }}=0.8582 \cdot d_{0}^{0.8474} \cdot G^{0.5537}, \\
& \mathrm{R}_{\text {adj }}^{2}=0.7269 ; \mathrm{RMSE}=24.72\left(\mathrm{Mg} \mathrm{ha}^{-1}\right) \\
& W_{\text {bark }}=0.2449 \cdot H_{0}^{0.4847} \cdot G^{0.6431}, \\
& \mathrm{R}_{\text {adj }}^{2}=0.6847 ; \mathrm{RMSE}=2.147\left(\mathrm{Mg} \mathrm{ha}^{-1}\right) \\
& W_{\text {crown }}=14.31 \cdot d_{0}^{1.221} \cdot H_{0}^{-1.649} \cdot G^{0.4965} \text {, } \\
& \mathrm{R}_{\text {adj }}^{2}=0.6347 ; \mathrm{RMSE}=7.299\left(\mathrm{Mg} \mathrm{ha}^{-1}\right) \\
& W_{\text {total }}=W_{\text {wood }}+W_{\text {bark }}+W_{\text {crown }}, \\
& \mathrm{R}_{\mathrm{adj}}^{2}=0.6864 ; \mathrm{RMSE}=33.56\left(\mathrm{Mg} \mathrm{ha}^{-1}\right) \\
& \operatorname{Ln} W_{\text {stem }}=-6.735+2.616 \cdot \operatorname{Ln} H_{0}+0.5386 \cdot \operatorname{Ln} N \text {, } \\
& \mathrm{R}^{2}{ }_{\text {adj }}=0.6743 ; \mathrm{RMSE}=27.97\left(\mathrm{Mg} \mathrm{ha}^{-1}\right) \\
& \operatorname{Ln} W_{\text {total }}=-5.186+2.229 \cdot \operatorname{Ln} H_{0}+0.5231 \cdot \operatorname{Ln} N \text {, } \\
& \mathrm{R}_{\text {adj }}^{2}=0.5683 ; \mathrm{RMSE}=37.64\left(\mathrm{Mg} \mathrm{ha}^{-1}\right)
\end{aligned}
$$

Where, $W_{\mathrm{i}}$ : dry weight of the $i$ biomass component $(\mathrm{Mg}$ ha $\left.{ }^{-1}\right), d_{0}$ : dominant diameter $(\mathrm{cm}), H_{0}$ : dominant height (m), $G$ : basal area $\left(\mathrm{m}^{2}\right.$ ha-1), $N$ : stand density $\left(\right.$ stems ha $\left.{ }^{-1}\right)$, RMSE: root mean square error, $\mathrm{R}_{\text {adj }}^{2}$ : coefficient of determination.

Yield tables. The yield tables were constructed based on the methodology reported by Sánchez et al. (2003) using the equations [2] - [4], [5], [7], [10] - [13]. The merchantable volumes included in these tables are the most useful according to the current wood market in northwestern Spain $\left(V_{15}, V_{20}, V_{40}\right)$. Tables 2 to 9 (Appendix) show the eight yield tables developed for four site indices $(8,12,16$ and 20) and two density classes ("high" and "low").

According to this static model, the optimal rotation length (the one which produces the maximum sustainable yield) ranged between 25 and 45 years for the highest 
and lowest site indices, respectively. The mean annual increment for this rotation varied (depending on both stand density class and site index) from: $5.2 \mathrm{~m}^{3} \mathrm{ha}^{-1} \mathrm{year}^{-1}$ for the lowest density and poorest quality to $38.1 \mathrm{~m}^{3} \mathrm{ha}^{-1}$ year $^{-1}$ for the highest density and best quality.

Stand density management diagrams. Three SDMDs (figure 5) were developed by using the equations [6], [8], [14] and [15] for estimating $d_{\mathrm{g}}, V, W_{\text {stem }}, W_{\text {total }}$. Isolines for stand volume, stem biomass and stand aboveground biomass were represented by substituting these equations into equations [16] - [18], respectively, and solving for $N$ through a range of $H_{0}$ by setting $V, W_{\text {stem }}$ and $W_{\text {total }}$ constant:

$$
\begin{aligned}
& \mathrm{N}=\left(\frac{V}{0.005065 \cdot H_{0}^{2.455}}\right)^{1 / 0.5219} \\
& \mathrm{~N}=\left(\frac{W_{\text {stem }}}{0.001188 \cdot H_{0}^{2.616}}\right)^{1 / 0.5386} \\
& \mathrm{~N}=\left(\frac{W_{\text {total }}}{0.005594 \cdot H_{0}^{2.229}}\right)^{1 / 0.5231}
\end{aligned}
$$

Where, $N$ : stand density (stems ha $\left.{ }^{-1}\right), V$ : total stand volume ( $\left.\mathrm{m}^{3} \mathrm{ha}^{-1}\right), H_{0}$ : dominant height $(\mathrm{m}), W_{\mathrm{i}}$ : dry weight of the $i$ biomass component $\left(\mathrm{Mg} \mathrm{ha}^{-1}\right)$.

Total stand volume values range from 50 to $700 \mathrm{~m}^{3} \mathrm{ha}^{-1}$ and isolines slope upwards from left to right, according to the principle that productivity at any point in time is significantly affected by dominant height. The uppermost line of the relative spacing index corresponds to a value of $10 \%$, approximating the minimum relative spacing index represented in the data set. This value could be assumed as a reasonable approximation of the maximum size - density relationships for chestnut coppice stands in northwestern Spain.

\section{DISCUSSION}

Site index is a key variable for forest management because it is highly correlated with volume and biomass productivity. The GADA approach used in the present study to develop the dominant height growth model is much more accurate and precise than the guide curve method used for developing the pre-existent model in the region (Cabrera and Ochoa 1997). In addition, we used longitudinal data obtained from stem analyses, instead of dominant heightage pairs of data from temporary plots used by Cabrera and Ochoa (1997). Examination of the graphs showed that the SI curves provided the best description of individual growth trends for chestnut in coppice stands in northwestern Spain.

The optimal rotation length that produces the maximum sustainable yield varied from 45 years for the lowest site index $(8 \mathrm{~m})$ to 25 for the highest $(20 \mathrm{~m})$. The former rotation length ( 25 years) is lower than that reported by $\mathrm{Ca}$ brera and Ochoa (1997) (31 years) and by Elorrieta (1949) (30 years) and even than those proposed by Bourgeois et al. (2004) and Lemaire (2008) for high quality timber in France (40 - 45 years). Nevertheless, for the lowest site index, the estimated optimal rotation length is 8 years higher than that obtained for a previous study in the region (Cabrera and Ochoa 1997). The large differences in the rotation length for lowest site index may be explained by the different dominant height growth models used, and by the fact that the yield tables developed by Cabrera and Ochoa (1997) do not use an equation to explain density evolution over time. This lack may be due to the heterogeneity of the silvicultural stages of chestnut coppice stands in northwestern Spain. Nevertheless, in this study this heterogeneity in the stands was solved through the development of two-stand density models (high and low) in order to better explain the behavior of one of the most important factors in chestnut coppice stands.

According to yield tables, the productivity of chestnut coppice stands in the region is remarkably high, close to that of other species typically considered fast growing species such as pine or eucalyptus. The estimated growth in Asturias, especially for the better quality sites, is higher than that reported for other countries: $11 \mathrm{~m}^{3} \mathrm{ha}^{-1}$ year $^{-1}$ at 40 years in the Dean Forest in the south of England for the best qualities (Everard and Christie 1995), $10 \mathrm{~m}^{3} \mathrm{ha}^{-1}$ year at 30 years in Italy (Elorrieta 1949) and $16 \mathrm{~m}^{3} \mathrm{ha}^{-1}$ year ${ }^{-1}$ at 30 years in France (Bourgeois et al. 2004).

Nevertheless, the average diameter dimensions currently obtained in Asturias at rotation age are not as large as in France - quadratic mean diameter of $25.3 \mathrm{~cm}$ compared with $42.39 \mathrm{~cm}$, respectively - (Bourgeois et al. 2004, Lemaire 2008), mainly because of the stand densities -867 stems $\mathrm{ha}^{-1}$ for the lowest density and highest quality site compared with 180 stems ha $^{-1}$, respectively. More intensive management, together with higher quality sites, would allow production of high quality timber, which would be seriously appreciated in the timber market.

SDMDs and management options have been developed in many studies, e.g. Pérez-Cruzado et al. (2011) for Eucalyptus globulus Labill. and Eucalyptus nitens $\mathrm{H}$. Deane and Maiden, Castaño-Santamaría et al. (2013) for Quercus pyrenaica Willd. in northwestern Spain. This study presents in figure 6 an example of a thinning schedule similar to those proposed for the best site qualities and the most intensive interventions in France. In this schedule, it is assumed that the target harvest dominant height is $28 \mathrm{~m}$ with a quadratic mean diameter over $34 \mathrm{~cm}$. The upper growing stock limit is defined by a relative spacing index of $20 \%$ and the thinning intervals are based on dominant height increments of $7 \mathrm{~m}$. This figure also confirms the difference between stand densities in both countries since chestnut coppice stands in northwestern Spain present higher densities, in most of the cases over 800 stems ha-1. $^{-1}$. 

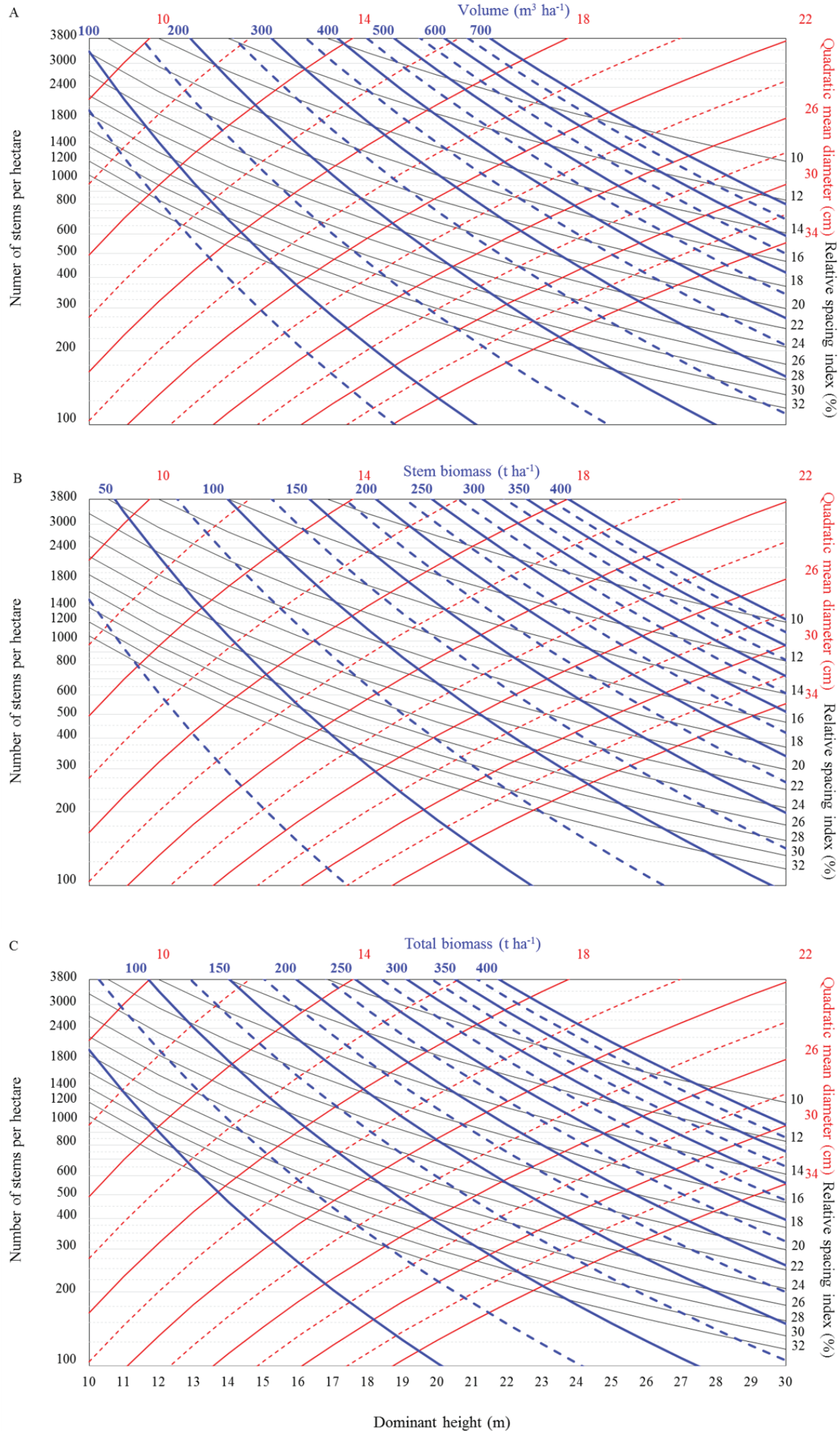

Figure 5. Stand density management diagrams for chestnut coppice stands in NW Spain for estimating stand volume (A), stem biomass (B), total biomass (C).

Diagramas de manejo de densidad para masas de monte bajo de castaño en el NO de España para la estimación de volumen total de la masa (A), biomasa de fuste (B), biomasa total (C). 


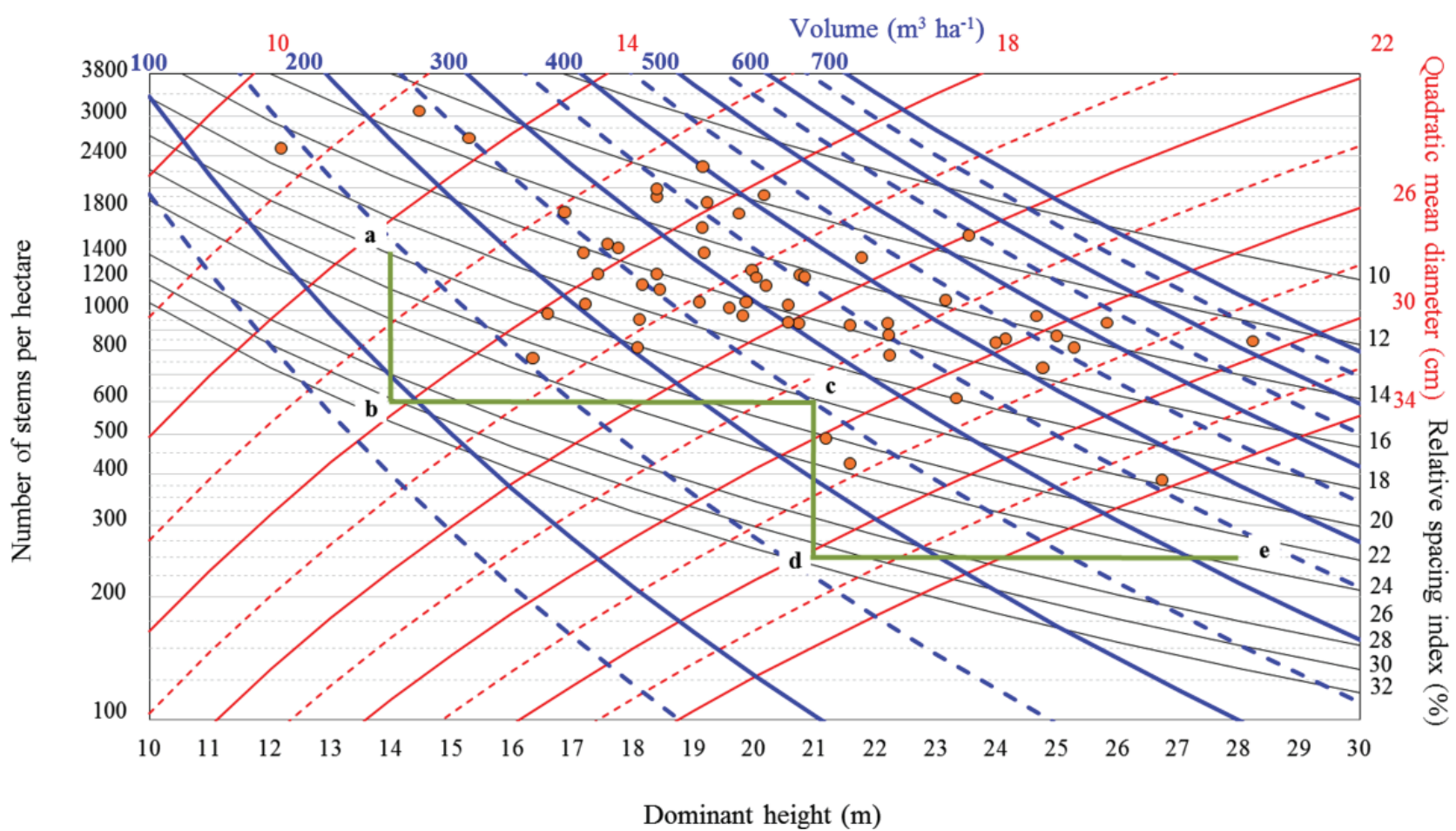

Figure 6. Example of silvicultural scheme proposed in France with a very intensive intervention in the best quality forests. The points identified sample plots used in the adjustment process.

Ejemplo de esquema selvícola propuesto en Francia con una intervención muy intensiva en las mejores calidades de estación. Los puntos identifican las parcelas de muestreo utilizadas en el proceso de ajuste.

\section{CONCLUSIONS}

Different management tools were developed for chestnut coppice stands in northwestern Spain and help determine the most appropriate practices for this type of stand. These models have a wide potential use because the data required for them are available from common forest inventories.

Four site indices were derived in this study for chestnut coppice stands in northwestern Spain. The indices were determined by the value of dominant height $(8,12,16$ and $20 \mathrm{~m}$ at a reference age of 20 years), according to the proposed site index curves.

The stand density models allow the explanation of the fact that stand density in coppice stands is closely related to historical silvicultural management, as a consequence of many stems growing in the same stool and competing for nutrients, water and space.

The stand biomass could be estimate with two different systems depending on the management tool applied. The first system enables calculation of stand biomass for different components implemented in the yield tables: wood, bark, crown and total biomass. The second system was fitted for stem and total biomass to be implemented in the stand density management diagrams.
The proposed equations for stand volume can also be used to estimate total volume to different top diameters or height limit, and can be used to estimate multi-product volumes in the same tree, independently from using the one implemented in the yield tables or in the SDMDs.

These management tools are very effective for the design, display and evaluation of alternative density management regimes in forest stands. Estimation of stand volume, stand biomass, site quality and carbon pools can help stakeholders and Public Administrations to test several indicators of sustainable forest management related to growing stocks. The SDMDs developed in this study allows the development in a relatively easy way of alternative thinning schedules that could be compared using economic criteria to facilitate management decisions. Here, we only show some of the diagrams developed. However, the other diagrams are available upon request.

As additional information becomes available, it can be overlaid on the SDMDs to facilitate management decisions, and dynamic growth models can be developed.

\section{ACKNOWLEDGEMENTS}

The authors thank Forest Services (Government of the Principality of Asturias), and the private owners who 
allowed the establishment of the permanent plots. This study was supported by the Spanish Ministry of Science and Innovation (MICIN) and the Plan for Science, Technology and Innovation of the Principality of Asturias (PCTI) as part of the research project "Forest and industrial evaluation of Spanish chestnut" (VALOCAS).

\section{REFERENCES}

Bertalanffy LV. 1949. Problems of organic growth. Nature 163: 156-158.

Bertalanffy LV. 1957. Quantitative laws in metabolism and growth. The Quarterly Review of Biology 32(3): 217-231.

Burkhart H.1977. Cubic-foot volume of loblolly pine to any merchantable top limit. Southern Journal of Applied Forestry 1: 7-9.

Burkhart HE, M Tomé. 2012. Modelling forest trees and stands. London, UK. Springer. $471 \mathrm{p}$.

Cabrera BM, F Ochoa. 1997. Tablas de producción de castaño (Castanea sativa Mill.) tratado en monte bajo, en Asturias. In Puertas F, M Rivas M eds. II Congreso Forestal EspañolIrati 97. Pamplona, Spain. p. 131-136.

Carmean WH. 1972. Site Index Curves for Upland Oaks in the Central States. Forest Science 18: 109-120.

Castaño-Santamaría J, M Barrio-Anta, P Álvarez-Álvarez. 2013. Regional-scale stand density management diagrams for Pyrenean oak (Quercus pyrenaica Willd.) stands in northwest Spain. iForest 6: 113-122.

Cieszewski CJ, RL Bailey. 2000. Generalized algebraic difference approach: a new methodology for derivation of biologically based dynamic site equations. Forest Science 46: 116-126.

Cieszewski CJ. 2002. Comparing fixed-and variable-base-age site equations having single versus multiple asymptotes. Forest Science 48: 7-23.

Cieszewski CJ. 2003. Developing a Well-Behaved Dynamic Site Equation Using a Modified Hossfeld IV Function $\mathrm{Y}^{3}=$ $\left(a x^{\mathrm{m}}\right) /\left(\mathrm{c}+\mathrm{x}^{\mathrm{m}-1}\right)$, a Simplified Mixed-Model and Scant Subalpine Fir Data. Forest Science 49: 539-554.

Clark A, CE Thomas. 1984. Weight equations for southern tree species. When are and what is needed. In Daniels RF, PH Dunhan eds. Proceedings of the 1983 southern forest biomass workshop. Fifth annual meeting of the Southern Forest Working Group, 1983 June 15-17. Charleston, SC Asheville, NC. USDA Forest Service. Southern Forest Experimental Station. p. 100-106.

DGCONA (Dirección General de Conservación de la Naturaleza, ES). 2013. III Mapa Forestal de España. MFE50. 1:50000. Ministerio de Medio Ambiente, Madrid, España.

Díaz Varela RA, MS Calvo Iglesias, ER Díaz Varela, P Ramil Rego, R Crecente Maseda. 2009. Castanea sativa forests: a threatened cultural landscape in Galicia NW Spain. In Krzywinski K, M O'Connell, H Küster eds. Cultural landscapes of Europe. Fields of demeter haunts of pan. Bremen, Germany. Aschembeck Media UG. p. 94-95.

Diéguez-Aranda U, HE Burkhart, R Rodríguez-Soalleiro.2005. Modelling dominant height growth of radiata pine (Pinus radiata D. Don) plantations in north-western Spain. Forest Ecology and Management 215: 271-284.

Drew TJ, JW Fleming. 1979. Stand density management: an al- ternative approach and its application to Douglas-fir plantations. Forest Science 25: 518-532.

Elorrieta J. 1949. El castaño en España. Instituto Forestal de Investigaciones Agrarias (I.F.I.E.). Número 48. Madrid, España. Ministerio de Agricultura. 303 p.

Everard J, JM Christie. 1995. Sweet chestnut: silviculture, timber quality and yield in the Forest of Dean. Forestry 68(2): 133-144.

Fang Z, BE Borders, RL Bailey. 2000. Compatible volume-taper models for Loblolly and Slash pine based on a system with segmented-stem form factors. Forest Science 46(1): 1-12.

Goelz JCG, TE Burk. 1992. Development of a well-behaved site index equation: jack pine in north central Ontario. Canadian Journal of Forest Research 22: 776-784.

Hummel FC, GM Locke, JN Jeffers, JM Christie. 1959. Code of sample plot procedure. London, UK. Her Majesty's Stationary Office. Forestry Commission Bulletin $\mathrm{N}^{\mathrm{o}} 31.114 \mathrm{p}$.

Lemaire J. 2008. Estimer la potentialité de son taillis de châtaignier et adapter les éclaircies. Forêt Enterprise 179: 14-17.

Madrigal A. 1991. Tablas de producción. In Seminario sobre inventario y ordenación de montes. Valsaín, Spain. Vol. II. p. 32-70.

Madrigal A, F Puertas, FJ Martínez-Millán. 1992. Tablas de producción para Fagus sylvativa L. en Navarra. Serie Agraria No3. Pamplona, España. Departamento de Agricultura, Ganadería y Montes, Gobierno de Navarra. 122 p.

McCarter JB, JN Long. 1986. A lodgepole pine density management diagram. Western Journal of Applied Forestry 1: 6-11.

McDill ME, RL Amateis. 1992. Measuring forest site quality using the parameters of a dimensionally compatible height growth function. Forest Science 38: 409-429.

Menéndez-Miguélez M, E Canga, M Barrio-Anta, J Majada, P Álvarez-Álvarez. 2013. A three level system for estimating the biomass of Castanea sativa Mill. coppice stands in north-west Spain. Forest Ecology and Management 291: 417-426.

Menéndez-Miguélez M, E Canga, P Álvarez-Álvarez, J Majada. 2014. Stem taper function for sweet chestnut (Castanea sativa Mill.) coppice stands in northwest Spain. Annals of Forest Science 71: 761-770.

Newberry JD. 1991. Note: A Note on Carmean's Estimate of Height from Stem Analysis Data. Forest Science 37: 368369.

Newton PF, Y Lei, SY Zhang. 2005. Stand-level diameter distribution yield model for black spruce plantations. Forest Ecology and Management 209: 181-192.

Pérez-Cruzado C, A Merino, R Rodríguez-Soalleiro. 2011. A management tool for estimating bioenergy production and carbon sequestration in Eucalyptus globulus and Eucalyptus nitens grown as short rotation woody crops in north-west Spain. Biomass and Bioenergy 35: 2839-2851.

Reed D, E Green. 1984. Compatible stem taper and volume ratio equations. Forest Science 30(4): 977-990.

Reineke LH. 1933. Perfecting a stand density index for evenaged forest. Journal of Agricultural Research 46: 627-638.

Richards FJ. 1959. A flexible growth function for empirical use. Journal of Experimental Botany 10: 290-301.

Sánchez F, R Rodríguez, A Rojo, JG Álvarez, CA López, JJ Gorgoso, F Castedo. 2003. Crecimiento y tablas de producción de Pinus radiata D. Don en Galicia. Investigación Agraria: Sistemas y Recursos Forestales 12(2): 65-83. 
SAS Institute Inc. 2004a. SAS/STAT®. 9.1. User's Guide. SAS Institute Inc., Cary, NC.

SAS Institute Inc. 2004b. SAS/ETS®. 9.1. User's Guide. SAS Institute Inc., Cary, NC.

Wilson FG. 1946. Numerical expression of stocking in terms of height. Journal of Forestry 44: 758-791.

Yoda K, H Kira, H Ogawa, K Hozumi. 1963. Self-thinning in overcrowded pure stands under cultivated and natural conditions. Journal of Biology (Osaka City University) 14: 170-129.

Recibido: 05.06.15

Aceptado: 16.11 .15 


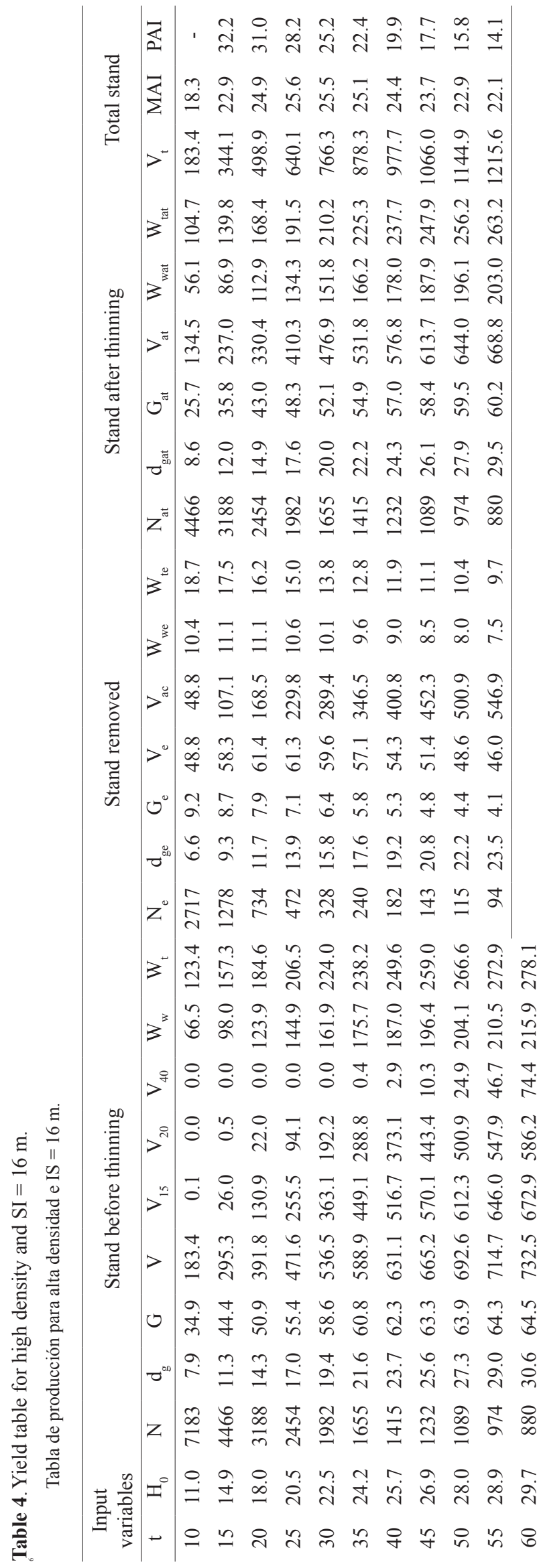

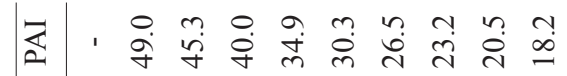

चี

픙

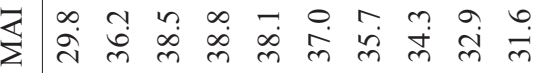

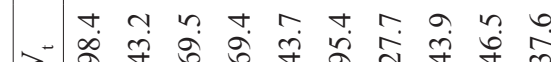

$>$ की में

ఫ

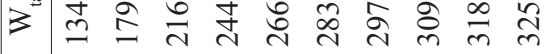

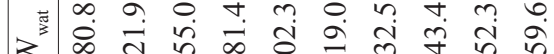

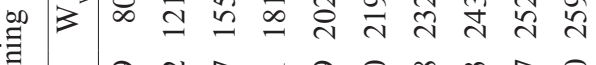

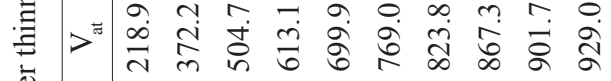

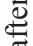

营

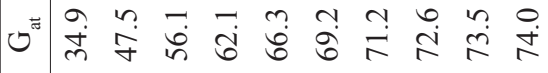

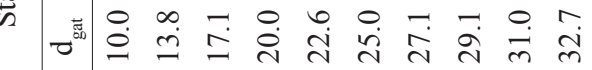

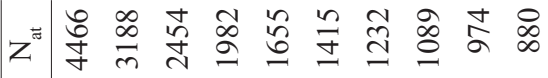

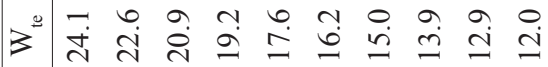

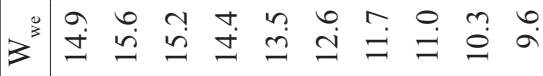

- $n$ n 0 .

गे

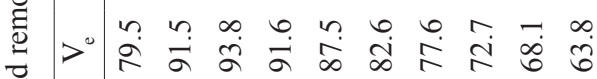

焉

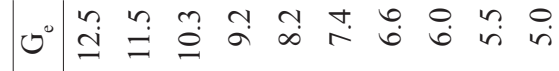

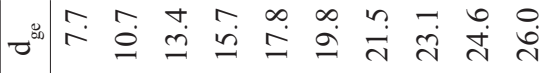

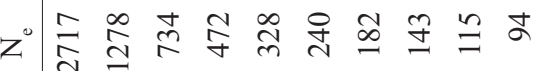

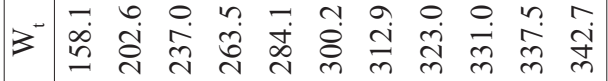

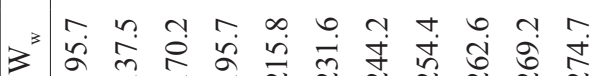

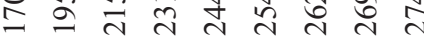

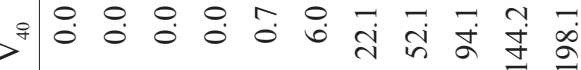

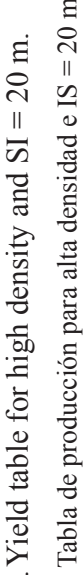

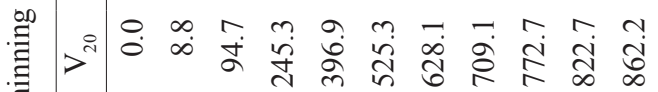

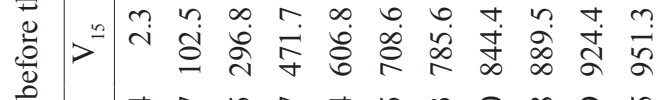

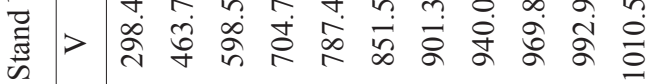

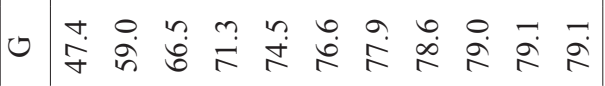

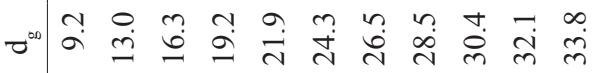

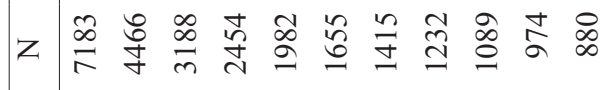

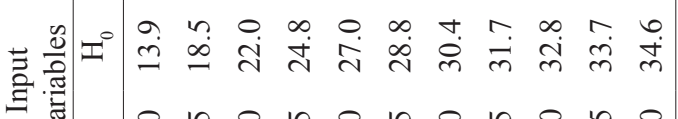




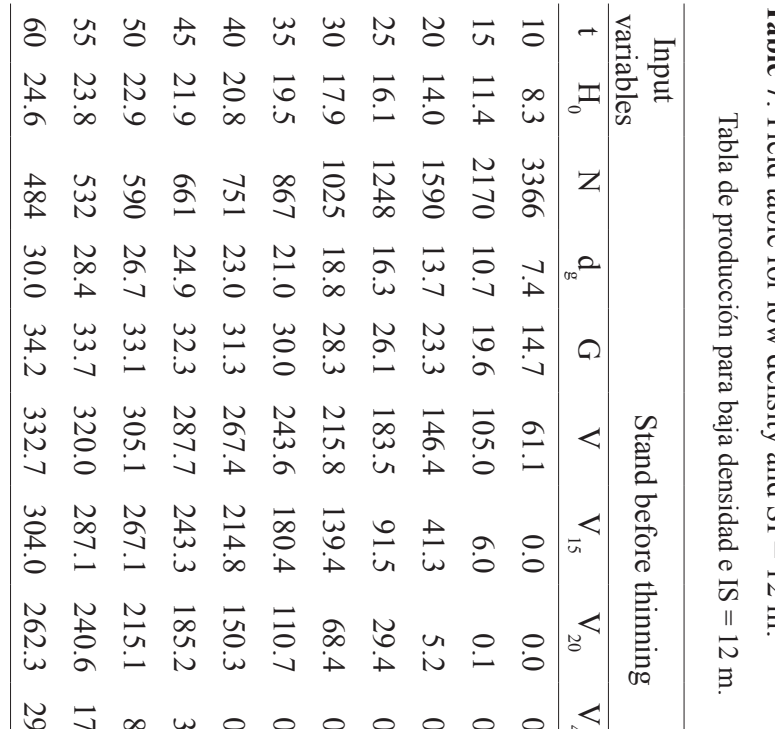

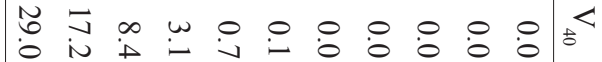

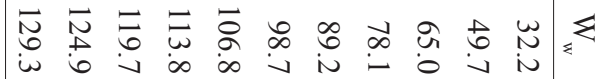

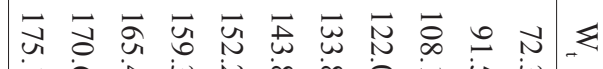
-

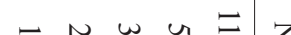

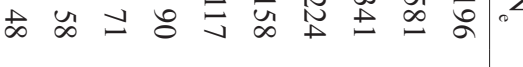

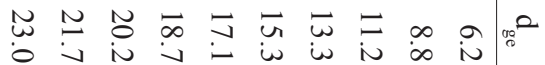

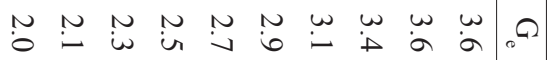

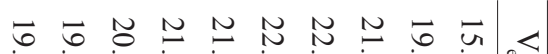

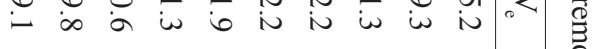

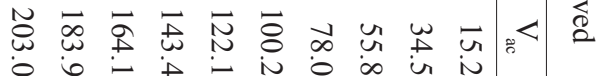

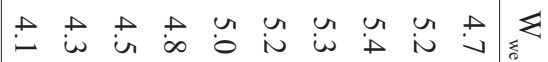

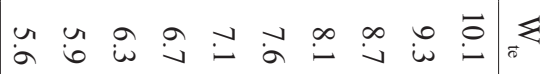

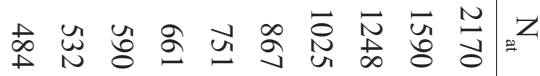

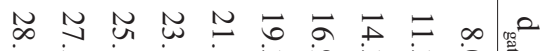

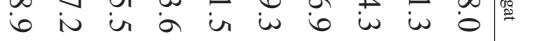

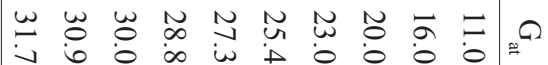
岁 i

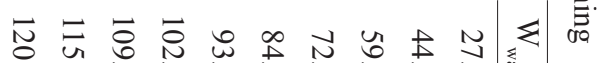
$\forall$ is $-\infty+\infty$ a

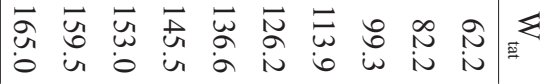

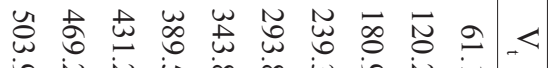
$b$ is is in $\infty$ is is iv i-

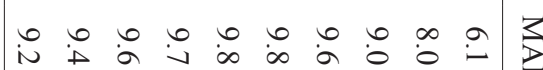
bे

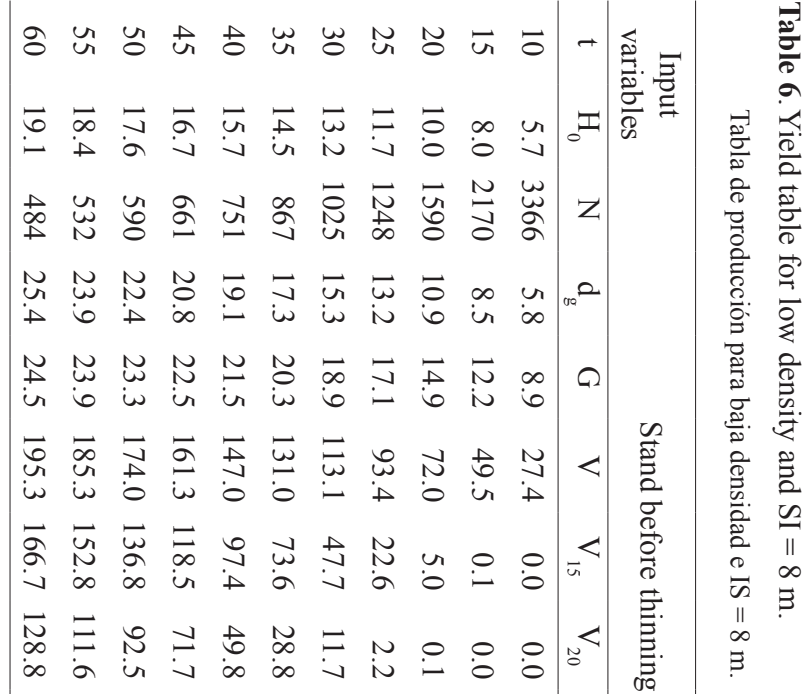

N $\infty$ 舟虫

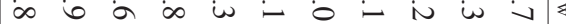

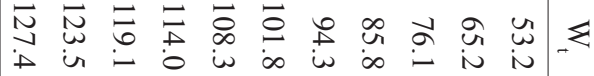

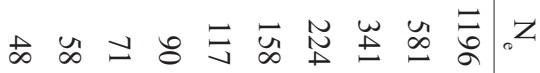

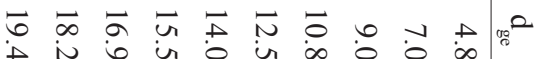

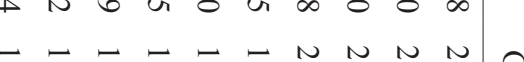

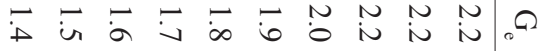

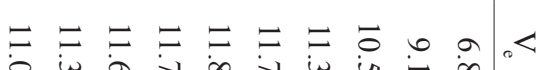
จ

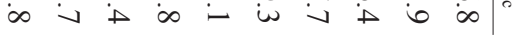

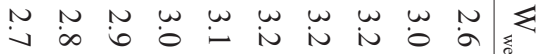

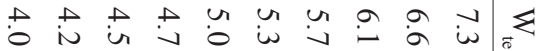
京 峛

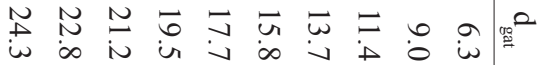

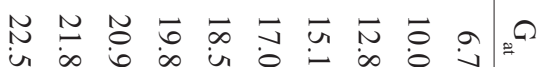

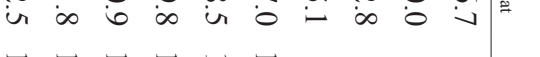

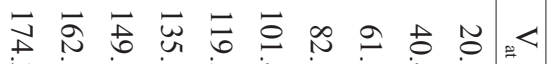

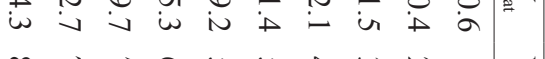

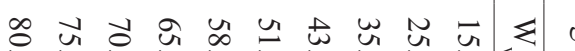

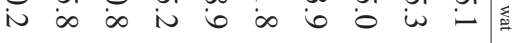

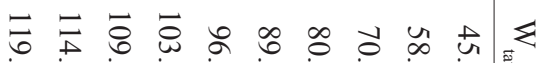

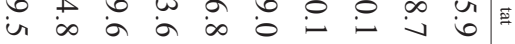
N

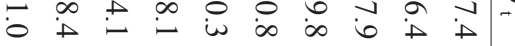

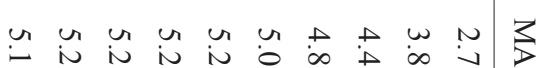
- in in is in o

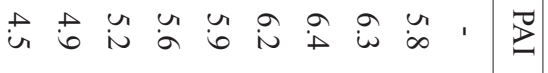



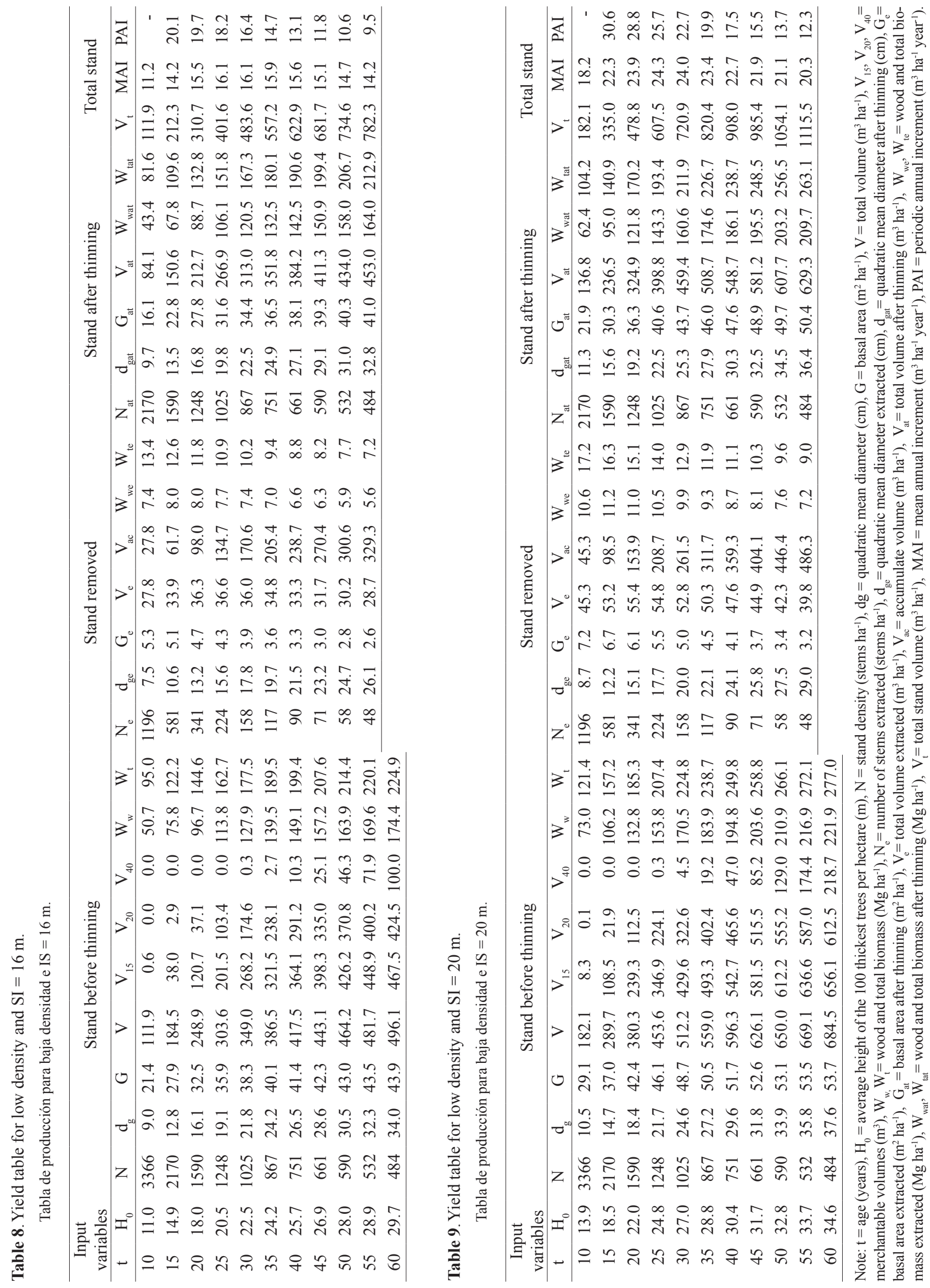
